\title{
SARMATIAN BARROW 1 OF KOTLOVINA I CEMETERY ON THE LEFT BANK OF THE LOWER DANUBE
}

\author{
Sergey O. Simonenko \\ Pridnestrovian State University named after T.G. Shevchenko, \\ Tiraspol, Pridnestrovian Moldavian Republic \\ Sergey D. Lysenko \\ Institute of Archaeology of the National Academy of Sciences of Ukraine, Kiev, Ukraine
}

\section{Sergey N. Razumov}

Pridnestrovian State University named after T.G. Shevchenko, Tiraspol, Pridnestrovian Moldavian Republic

\section{Vitalij S. Sinika}

Pridnestrovian State University named after T.G. Shevchenko, Tiraspol, Pridnestrovian Moldavian Republic

\begin{abstract}
Introduction. The paper deals with analyzing the Sarmatian burial complex investigated in 1990 in the barrow 1 of Kotlovina I cemetery located on the western shore of the lake Yalpug, $3 \mathrm{~km}$ to the south from the village of the same name in Reni district of Odessa region. Materials. The mound was surrounded by a circular ditch with a single gap in the south. Similar ditches were recorded on the Sarmatian sites of the North-Western Black Sea region, as well as on the territory of Hungary and in the Don region. The burial was made with an offset from the geometric center of the mound, apparently, in order to avoid robbery. The main and only grave was done in a pit with an undercut. The buried man laid under the western wall of the funeral ch chamber in an elongated position on his back, his head to the north. The accompanying inventory is represented by a red clay pottery jug, which was covered by a handmade lid-bowl, as well as a large handmade pot. A large one-handed red clay pottery jug is of particular interest. Such vessels were widespread in the North Black Sea region, and their findings are known both in funeral complexes and in ancient settlements of the Roman time. The large size of the handmade lid-bowl, as well as the presence of traces of fuliginosity makes it possible to assume its dual purpose: as tableware during life and as a lid of the pottery vessel for the internment. The handmade pot is distinguished by an ornament in the form of impressions on the upper part of the body, forming a triangle. Conclusions. The analysis of the features of the funeral rite and the time of the inventorys existence make it possible to date the barrow to the $2^{\text {nd }}-3^{\text {rd }}$ centuries AD. Grave 1 from barrow 1 of Kotlovina I cemetery clarifies the historical picture of the stay of Sarmatian tribes in the North-West Black Sea region, in particular, on the left bank of the Lower Danube.

Key words: Sarmatians, circular ditch with a gap in the southern part, North-West Black Sea region, grave, undercut, red clay jug, handmade lid-bowl, handmade pot.

Citation. Simonenko S.O., Lysenko S.D., Razumov S.N., Sinika V.S. Sarmatian Barrow 1 of Kotlovina I Cemetery on the Left Bank of the Lower Danube. Vestnik Volgogradskogo gosudarstvennogo universiteta. Seriya 4. Istoriya. Regionovedenie. Mezhdunarodnye otnosheniya [Science Journal of Volgograd State University. History. Area Studies. International Relations], 2020, vol. 25, no. 4, pp. 168-180. (in Russian). DOI: https://doi.org/10.15688/ jvolsu4.2020.4.11




\section{САРМАТСКИЙ КУРГАН 1 МОГИЛЬНИКА КОТЛОВИНА І НА ЛЕВОБЕРЕЖЬЕ НИЖНЕГО ДУНАЯ}

\section{Сергей Олегович Симоненко}

Приднестровский государственный университет им. Т.Г. Шевченко, г. Тирасполь, Приднестровская Молдавская Республика

\section{Сергей Дмитриевич Лысенко}

Институт археологии Национальной академии наук Украины, г. Киев, Украина

\section{Сергей Николаевич Разумов}

Приднестровский государственный университет им. Т.Г. Шевченко, г. Тирасполь, Приднестровская Молдавская Республика

\section{Виталий Степанович Синика}

Приднестровский государственный университет им. Т.Г. Шевченко, г. Тирасполь, Приднестровская Молдавская Республика

Аннотация. Статья посвящена анализу сарматского погребального комплекса, исследованного в 1990 г. в кургане 1 могильника Котловина I, расположенного на западном берегу озера Ялпуг, в 3 км к югу от одноименного села Ренийского района Одесской области. Насыпь была окружена кольцевым рвом с единственным разрывом на юге. Подобные рвы зафиксированы на сарматских памятниках Северо-Западного Причерноморья, а также на территории Венгрии и в Подонье. Погребальный комплекс был устроен со смещением от геометрического центра кургана, по всей видимости, во избежание ограбления. Основное и единственное захоронение было совершено в яме с подбоем. Погребенный лежал под западной стенкой камеры в вытянутом положении на спине, головой на север. Сопровождающий инвентарь представлен красноглиняным гончарным кувшином, который накрывала лепная крышка-миска, а также большим лепным горшком. Особый интерес представляет большой одноручный красноглиняный гончарный кувшин. Подобные сосуды имели широкое распространение в Северном Причерноморье, и их находки известны как в погребальных комплексах, так и на городищах римского времени. Большие размеры лепной крышкимиски, а также наличие следов закопченности дают возможность предполагать ее двойное назначение: в качестве столовой посуды при жизни и в качестве крышки гончарного сосуда во время захоронения. Лепной горшок выделяется орнаментом в виде вдавлений на верхней части тулова, образующих треугольник. Проведенный анализ особенностей погребального обряда и времени бытования инвентаря позволил датировать курган II-III вв. н. э. Вклад авторов. С.О. Симоненко подготовлена аналитическая часть работы. С.Д. Лысенко зарисовал находки из кургана и описал их. С.Н. Разумов выполнил чертежи плана кургана и плана погребения, а также описание конструкций. В.С. Синика провел работу по сверке полевой документации и материалов в фондах Измаильского историко-краеведческого музея, а также участвовал в подготовке аналитической части работы.

Ключевые слова: сарматы, кольцевой ров с разрывом в южной части, Северо-Западное Причерноморье, погребение, подбой, красноглиняный кувшин, лепная крышка-миска, лепной горшок.

Цитирование. Симоненко С. О., Лысенко С. Д., Разумов С. Н., Синика В. С. Сарматский курган 1 могильника Котловина I на левобережье Нижнего Дуная // Вестник Волгоградского государственного университета. Серия 4, История. Регионоведение. Международные отношения. - 2020. - T. 25, № 4. - C. 168-180. - DOI: https:/ /doi.org/10.15688/jvolsu4.2020.4.11

Введение. В 1990 г. археологической экспедицией Одесского областного управления Общества охраны памятников истории и культуры под руководством М.М. Фокеева был исследован курганный могильник Котловина I, располагавшийся на западном берегу озера Ялпуг, в 3 км к югу от одноименного села Ренийского района Одесской области. Среди 
курганов, сооруженных в раннем бронзовом веке и в скифское время, находились и курганы, возведенные в сарматскую эпоху.

В 1960-1980-е гг. исследования археологических памятников в Одесской области носили систематический характер, что позволило изучить значительное число сарматских погребений. Однако бо́льшая часть из них была ограблена еще в древности. Погребальный комплекс, анализируемый в настоящей работе, хотя и не принадлежал представителю сарматской аристократии, оказался нетронутым, что делает его, наряду с еще несколькими неограбленными захоронениями региона, весьма ценным источником для изучения истории сарматского присутствия в Северо-Западном Причерноморье.

Данная статья посвящена анализу сарматского кургана 1. Отметим, что тезисная публикация данного комплекса была сделана 12 лет назад [23], однако полного анализа всей полученной информации о погребальном обряде и инвентаре проведено не было, что не позволяло корректно рассматривать данное захоронение в кругу синхронных сарматских древностей Дунай-Днестровского междуречья и, шире, Северного Причерноморья.

Материалы. Курган был полностью распахан. Его насыпь исследовалась параллельными траншеями, разбитыми по направлению запад-восток, с сохранением центральной бровки. В ходе раскопок были обнаружены ров и единственное сарматское захоронение.

Кольцевой ров правильной округлой формы диаметром 11 м. Максимальная ширина составляла 0,5 м, глубина достигала 1,3 м от $R_{0}$. В южной части рва имелся разрыв шириной 1 м (рис. 1,1 ).

Погребение 1 (сарматское основное) обнаружено в 2 м к юго-востоку от $R_{0}$. Захоронение было совершено в подбое. Погребальное сооружение ориентировано по линии север-юг (рис. 1, 2, 3).

Входная яма подпрямоугольной формы с сильно закругленными углами, длиной 2 м, шириной около 0,5 м. Подбой располагался под западной стенкой. По дну яма имела прямоугольную форму с закругленными углами, длиной 2 м, шириной 0,95 м. Глубина входной ямы и подбоя 1,55 м.
Погребенный лежал в вытянутом положении на спине, головой на север. Руки были вытянуты вдоль тела. Правая кисть положена под тазовую кость, кости левой кисти не сохранились. Ноги прямые, кости стоп не сохранились (рис. 1).

Слева от ноги погребенного, возле южной стенки ямы, стоял большой красноглиняный гончарный кувшин (1). Рядом с горловиной кувшина находилась лепная коническая крышка-миска (2) и стоял вверх дном лепной горшок (3).

Описание находок. 1. Большой гончарный кувшин (рис. 2, 2). Край венчика Г-образно утолщен наружу, закруглен. Снизу венчик подчеркнут горизонтальным желобком. Горловина практически цилиндрическая, бочонковидная. Корпус асимметрично-биконический, с максимальным расширением в верхней половине. Дно округлое, с кольцевым поддоном, изнутри - вогнутое. Поддон высокий кольцевидный, в виде перевернутого усеченного конуса. Ручка ленточная, незначительно возвышающаяся над срезом венчика. Внешняя поверхность ручки вогнутая, внутренняя - выпуклая; боковые торцы закруглены. Верхний прилеп расположен непосредственно под венчиком, в 11 мм ниже среза; нижний прилеп - непосредственно выше ребра сосуда. Тесто хорошо отмученное, с примесью мелкого песка. Цвет розовато-оранжевый. Поверхности заглаженные, со следами вертикальных расчесов. Диаметр венчика 105,5 мм. Диаметр горловины под венчиком (по желобку) - 100 мм. Высота сосуда - 446449 мм, сосуда вместе с ручкой - 454 мм, венчика - 8-9 мм, горловины - 98 мм. Высота нижней части сосуда (вместе с ножкой) - 270275 мм, ножки-поддона - 45 мм. Расстояние от плоскости среза поддона до центра внешней поверхности дна сосуда - 16 мм, до места прилепа поддона - 30 мм. Максимальный диаметр горловины - 104 мм. Диаметр основания горловины - 90 мм, тулова - до 329 мм. Диаметр основания поддона - 68 мм, нижнего среза поддона - 98 мм. Толщина венчика 9,5-10 мм, стенок - 6-7 мм, дна - 7-8 мм, стенок поддона - 7-7,5 мм. Высота ручки до 180 мм, ручки над срезом венчика - 5 мм. Размеры сечения ручки: верхнего прилепа $73 \times 25$ мм, верхней части $-62 \times 20$ мм, сред- 
ней части $-60 \times 18$ мм, нижней части $-62 \times$ 16 мм, нижнего прилепа - около $83 \times 25$ мм. Внешняя поверхность ручки вогнута до 4 мм.

2. Лепная коническая крышка-миска (рис. 2, 1). Край венчика слегка утолщен наружу, уплощен под $60^{\circ}$; углы закруглены. Ручка-ножка коническая, вогнутая в центре. Тесто с примесью шамота. Цвет внешней поверхности серый, черный; внутренней поверхности и в изломе - черный. Местами прослеживается черный нагар. Поверхности шероховато-заглаженные, бугристые. Высота сосуда - 93 мм. Высота ручки-ножки - 15-18 мм. Диаметр венчика - 195200 мм. Размеры плоскости ручки-ножки $49 \times 53$ мм. Диаметр основания ручки-ножки - до 43 мм. Толщина венчика - 8-9,5 мм, стенок - 9-13 мм, «дна» в центре - 21 мм. Диаметр выемки в центре ручки-ножки 20 мм, глубина - до 9 мм.

3. Большой лепной горшок (рис. 3). Венчик воронковидный, со слегка отогнутым закругленным краем. Корпус округлобокий, с максимальным расширением в верхней половине сосуда. Днище слабо вогнутое, изнутри - выпуклое. Тесто с примесью шамота. Цвет желтовато-серый, серый, черный. Поверхности шероховато-заглаженные, бугристые, со следами сглаженных наклонных и вертикальных расчесов гребенкой (?). На внешней поверхности горловины - вертикальные расчесы гребенкой, на внутренней - горизонтальные расчесы. Высота сосуда - 288-296 мм, венчика - 45-49 мм, нижней части сосуда - 175180 мм. Диаметр венчика -212-215 мм, шейки - 194 мм, тулова - до 258 мм, дна - до 98 мм. Толщина венчика $-7-8$ мм. Толщина дна в центре - 19 мм, у стенок - 16 мм; дно вогнуто в центре до 1 мм. Сосуд орнаментирован с двух противолежащих сторон в верхней части плечика, немного ниже основания горловины, строенными пальцевыми вдавлениями, образующими треугольник.

Анализ. Зафиксированный погребальный обряд и инвентарь из захоронения позволяют констатировать, что курган 1 могильника Котловина I был возведен сарматами. Насыпь к моменту исследования не сохранилась, как и у большинства подобных небольших погребальных сооружений в степях Северо-Западного Причерноморья.
Особенностью погребального обряда рассматриваемого комплекса является наличие кольцевого рва правильной формы с разрывом в южной части.

К настоящему времени в Северо-Западном Причерноморье кольцевые рвы были исследованы как возле курганных захоронений, так и возле грунтовых. Особенностью этих рвов является их округлая форма с разрывом в южной части (в одном случае - в северной), имеются также сооружения без разрыва.

Кольцевые рвы с разрывами окружали следуюшие погребения: Обилены 5/2 [25, p. 56, fig. 46] на правобережье Нижнего Прута; Казаклия $5 / 3$ и $22 / 1$ [1; 7, с. 74-75] в ПрутскоДнестровском междуречье; в курганах 12 могильника Хаджидер II [19, с. 23, рис. 11, 1] и 11 могильника Дивизия [20, с. 10, рис. 8, 15] в Дунай-Днестровском междуречье; в курганах 19 Васильевского могильника [21, с. 10, рис. 7, 15], 9 могильника Кубей [21, с. 20, рис. 20,1$]$ и 11 могильника Градешка [9, с. 180, рис. 1, 2, 3] на левобережье Нижнего Дуная. За исключением комплекса у с. Обилены, где кольцевой ров имел разрыв в северной части, все остальные имели разрывы в южной.

Рвы без разрывов отмечены в курганах 23 и 25 Васильевского могильника [21, с. 11, $13-14$, рис. 11,7 , рис. 12,1$]$, а также в кургане 18 у с. Казаклия [7, с. 93].

В ходе исследования грунтового могильника Петрешты в Среднем Попрутье [24] обнаружено 13 кольцевых рвов с разрывами в южной части. Как и в случае с курганными комплексами, внутри рвов находились погребения. Данный факт позволяет заключить, что кольцевые рвы как один из элементов погребальной обрядности применялись и в подкурганных комплексах, и на грунтовых могильниках. Кроме того, во всех случаях окруженные рвами погребения являлись основными для своих курганных насыпей и комплексов в грунтовых могильниках.

Перечисленные выше комплексы с кольцевыми рвами сооружались сарматами на протяжении длительного периода - первых четырех веков нашей эры. Так, комплекс Обилены 5/2 датируется I-II вв. н. э. [25, р. 90], Казаклия 5/3 - II в. н. э. [7, с. 74-75]. Серединой II - первой половиной III в. н. э. датированы погребение Казаклия 22/1 [1, с. 291], кур- 
ганные могильники Хаджидер II [19, с. 2], Дивизия $[20$, с. 1] и Васильевский $[21$, с. 1]. Более поздним временем (III-IV вв. н. э.) датируются комплексы Казаклия 18/1 [7, с. 93] и Кубей 9 [22, с. 88-89], а также Градешка 11/1 (вторая половина III - начало IV в. н. э.) [9, c. 189]. Грунтовый могильник Петрешты, вероятнее всего, также относится к поднесарматскому времени.

А.В. Симоненко относит круглые рвы к пятому типу ритуальных сооружений и отмечает, что различные по конфигурации ритуальные площадки-рвы локализованы на сарматских памятниках Днестра и Прута, Венгрии и Дона. В восточной части ареала позднесарматских памятников они не обнаружены [17, c. 171-172].

Захоронения в подбоях становятся преобладающим типом погребальных сооружений в Северном Причерноморье, от Дона до Дуная, во второй половине II-III в. н. э. А.В. Симоненко связывал данный момент с появлением в Северном Причерноморье нового населения (новой волны) [15, с. 118$]$.

А.С. Скрипкин прослеживал распространение данного погребального обряда с востока на запад, отмечая у поздних сарматов Нижнего Поволжья преобладание подбоев на протяжении третьей четверти II - середины III в. н. э. Сооружение подбоя в западной стенке в рассматриваемом А.С. Скрипкиным регионе зафиксировано в 80 \% исследованных погребений [18, с. 60-61, 101].

В Северо-Западном Причерноморье количество подбойных могил меньше, чем на территории Нижнего Поволжья и Заволжья, и, по данным В.И. Гросу, отнесшего данный тип погребальных конструкций к четвертому типу, составляет 3,6 \% (20 могил) от общего числа изученных комплексов [7, с. 32]. В свою очередь, на Петрештском могильнике доля подобных погребальных конструкций составляет 25,71 \% от общего числа сарматских погребений [24]. Несмотря на относительно низкий по сравнению с Нижним Поволжьем показатель, ямы с подбоем имеют высокий удельный вес, и большинство захоронений с такой конструкцией расположены на западе Сарматии - в могильниках Подунавья и Поднестровья. Кроме того, подбойные погребения ориентированы с небольшими отклонениями на север [16, с. 149-150].
Во всех приведенных выше комплексах с кольцевыми рвами погребения расположены в центральной части. Исключением являются погребения 1/1 могильника Котловина I (рис. 1, 1) и 11/1 могильника Градешка [9, c. 180 , рис. 1, 2]. В обоих случаях захоронения, совершенные в катакомбах, смещены к восточной поле кургана. По всей видимости, такая практика использовалась сарматами для предотвращения раграбления могил.

Среди полученного из погребения сопровождающего инвентаря особый интерес представляет большой биконический одноручный гончарный кувшин на высоком кольцевом поддоне. Несмотря на широкие датировки в пределах конца I в. до н. э. - IV в. н. э., сосуд является индикатором торгово-экономических связей сарматов с соседними племенами и народами.

Большие гончарные кувшины имеют широкое распространение в Северо-Западном Причерноморье. Отметим, что центр производства таких сосудов остается неизвестным либо определяется предположительно.

В то же время рамки их бытования определяются датировкой тех археологических контекстов, где они были найдены. Так, целые и фрагментированные большие амфороидальные кувшины, обнаруженные в районе Истрии, датируются в пределах I-III вв. н. э. [26, р. 158159, fig. 75-77]. В Никонии, на левобережье Днестровского лимана, обнаружены многочисленные фрагменты и целые экземпляры красноглиняных кувшинов. Они найдены в перемещенных слоях и в ямах (в качестве урн для детских захоронений) и датируются I-III вв. н. э. [3, с. 34. рис. $11,5-6$, рис. 12]. В Ольвии аналогичные сосуды были обнаружены в слоях II-III вв. н. э. [12, с. 104]. На Козырском городище (Нижнее Побужье) подобные красноглиняные кувшины встречаются в период с конца I в. до н. э. до середины III в. н. э. [4, с. $102-103$, табл. 10,18$]$.

Близкий по форме кувшин (погребальная урна) происходит из раскопок Херсонеса в Крыму и датируется более широко - I в. до н. э. - IV в. н. э. [13, с. 115 , рис. 19, 2]. На городище Золотой Мыс в Побужье аналогичные сосуды датируются III в. н. э. Кроме того, авторы отмечают, что близкие провинциальноримские кувшины из Дакии датируют- 
ся II или II-III вв. н. э. [6, с. 30 , рис. $5,1,3]$. В склепе № 736 Усть-Альминского грунтового могильника (Юго-Западный Крым), датируемого I-II вв. н. э., обнаружен почти полный профиль и верхняя часть еще одного кувшина рассматриваемого типа [14, с. 207, 209, рис. $3,1,2]$. Такие же кувшины обнаружены в подбойных могилах № 700 и 852 Усть-Альмы с погребениями второй четверти - середины II в. н. э. Отмечается, что посуда этого типа часто встречается в античных центрах Причерноморья в комплексах II-III вв. н. э. [13, c. 209]. Кувшин из городища Бельбек IV в Юго-Западном Крыму датируется также второй четвертью - серединой II в. н. э. [10, с. 19, табл. 143, 14]. Целый кувшин, отнесенный к местной гончарной посуде, происходит из Мирмекия (Восточный Крым). Он был обнаружен над кладкой 144 и датирован В.Ф. Гайдукевичем II в. н. э. [5, с. 169, рис. 61]. В более позднем издании хронологические рамки бытования этого кувшина пересмотрены - он датируется I-III вв. н. э. [11, с. 229, табл. CXXXVIII, рис. 30].

Лепная коническая крышка-миска, лежавшая рядом с горловиной кувшина в погребении 1/1 могильника Котловина I, могла его накрывать. Однако наличие нагара на стенках крышки-миски может свидетельствовать и о ее использовании в качестве столовой посуды. При этом мы не исключаем двойное назначение этого изделия - в качестве миски в повседневной жизни и в качестве крышки гончарного сосуда в захоронении.

Подобные лепные сосуды достаточно широко представлены в сарматских комплексах Северо-Западного Причерноморья со второй половины I в. н. э. до ІІІ в. н. э. Однако необходимо отметить, что морфологически близкие изделия отличаются друг от друга диаметрами - от 8,3 см до 28 см. Несомненно, такая разница в диаметрах обусловлена параметрами сосудов, для накрывания которых они предназначались.

Особенностью лепной крышки-миски из погребения 1/1 могильника Котловина I является большой диаметр ее основания (20 cм). Аналогичные, наиболее крупные по диаметру крышки происходят из погребения I-II вв. н. э. Михайловка $2 / 2$ (диаметр - 20 см) в ДунайДнестровском междуречье [20, с. 19 , рис. 15 ,
$8]$, из захоронений второй половиной II - первой половины III в. н. э. Дивизия 2/1 и 7/1 (обе диаметром 22 см) в Дунай-Днестровском междуречье [20, с. 3,6 , рис. 2,8 , рис. 6,7$]$, из кургана II-III вв. н. э. Дзинилор 5 (диаметр 28 см) на левобережье Нижнего Дуная [8, с. 36 , рис. 11,1$]$.

Большой лепной округлобокий горшок с воронковидным, слегка отогнутым и закругленным венчиком является наиболее распространенным типом лепной сосуды на памятниках римского времени в Северном Причерноморье.

Особенностью данных сосудов выступает то, что в них зачастую отражаются традиции изготовления кухонной лепной керамики, присущие иным этническим группам, попавшим в сарматскую среду, в результате чего она становится традиционной сарматской посудой. Соответственно, такие сосуды анализируются исследователями в контексте всего погребального комплекса [2, с. 65].

Морфологически близкие сосуды имеют широкое распространение в подкурганных и грунтовых сарматских захоронениях СевероЗападного Причерноморья.

Однако особенностью нашего сосуда является наличие с двух противоположных сторон в верхней части плечика строенных пальцевых вдавлений, образующих треугольники. В Дунай-Днестровском междуречье такой вид орнаментации сосуда встречается впервые.

В керамическом комплексе Никония римского времени среди лепных горшков известна орнаментация ямками по тулову ниже венчика. На одном сосуде имелись вдавления в верхней части тулова, которые были расположены в виде треугольников [3, с. 58 , рис. 28,2$]$.

Необходимо отметить, что положение горшка вверх дном может быть связано с особенностями погребальной обрядности у сарматских племен.

Датировка комплекса и заключительные положения. Исходя из анализа погребального обряда и сопровождающего инвентаря, можно констатировать, что курган 1 могильника Котловина I был сооружен во II-III вв. н. э. Ранее этот комплекс датировался второй половиной II - первой половиной 


\section{АРХЕОЛОГИЯ РАННЕГО ЖЕЛЕЗНОГО ВЕКА}

III в. н. э. [23, с. 165], однако, как мы показали, оснований для столь узкой даты в настоящее время нет.

Погребение 1/1 могильника Котловина I уточняет историческую картину пребывания сарматских племен в Северо-Западном Причерноморье, в частности на левобережье Нижнего Дуная.

Погребальный обряд объединил в себе такие ставшие традиционными для позднесарматских памятников региона элементы, как кольцевой ров с одним разрывом в южной части, погребальная конструкция в виде подбоя, а также ориентировка умершего головой на север. В данном кургане зафиксировано весьма редкое явление в погребальной архитектуре, когда основное захоронение было намеренно смещено от геометричес- кого центра кургана, очевидно, во избежание его ограбления.

Кроме этого, можно отметить, что впервые в закрытом и непотревоженном комплексе был найден целый одноручный гончарный красноглиняный кувшин на высоком кольцевом поддоне. Происхождение таких кувшинов окончательно не установлено, но они получили широкое распространение на пространствах от Западного Причерноморья до Крыма.

Благодарности. Выражаем искреннюю признательность директору музея О.М. Тирон и главному хранителю фондов Г.П. Сюпюр Измаильского историко-краеведческого музея Придунавья (г. Измаил Одесской области Украины), где хранится коллекция из курганов могильника Котловина I, за возможность изучения материалов из публикуемого погребения. 

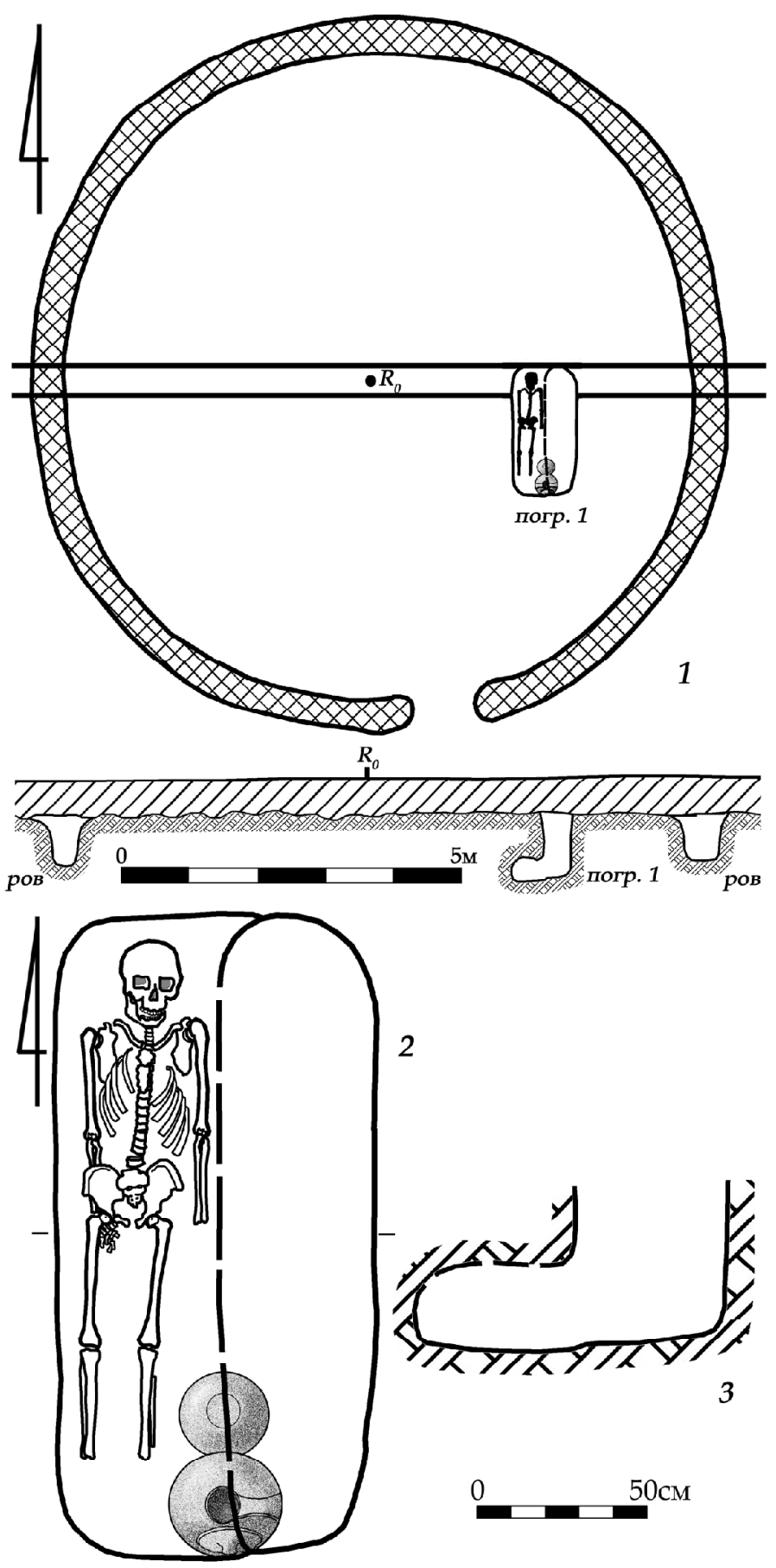

Рис. 1. Сарматский курган 1 могильника Котловина I на Нижнем Дунае: 1 - план кургана; 2, 3 - погребение 1

Fig. 1. Sarmatian barrow 1 of Kotlovina I cemetery in the Lower Danube region: 1 - plan of the barrow; 2,3- burial 1 


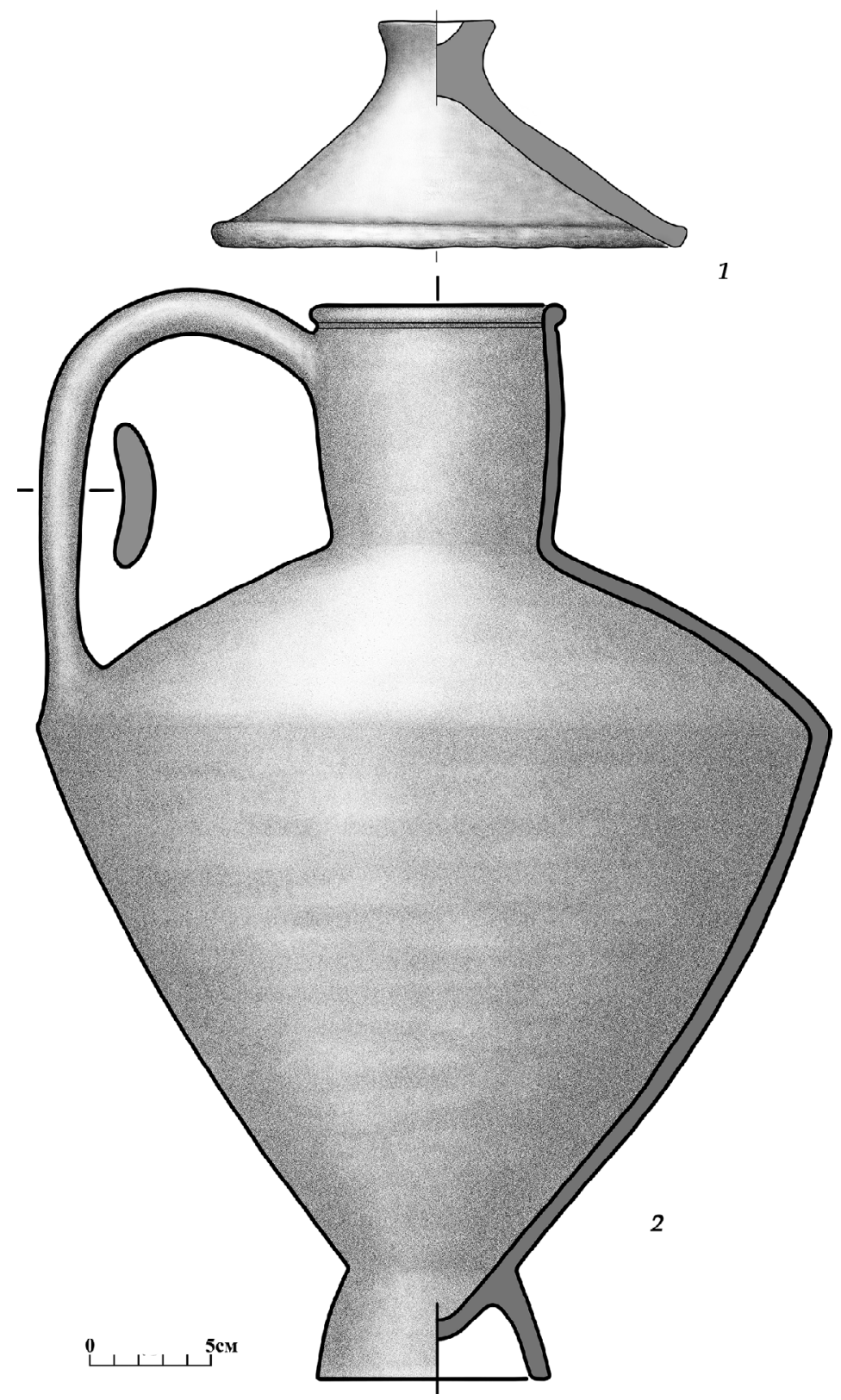

Рис. 2. Материалы из погребения 1/1 могильника Котловина I:

1 - лепная крышка-миска; 2 - гончарный кувшин

Fig. 2. Materials from burial $1 / 1$ of Kotlovina I cemetery:

1 - handmade lid-bowl; 2 - pottery jug 
Сарматский курган 1 могильника Котловина I на левобережье Нижнего Дуная

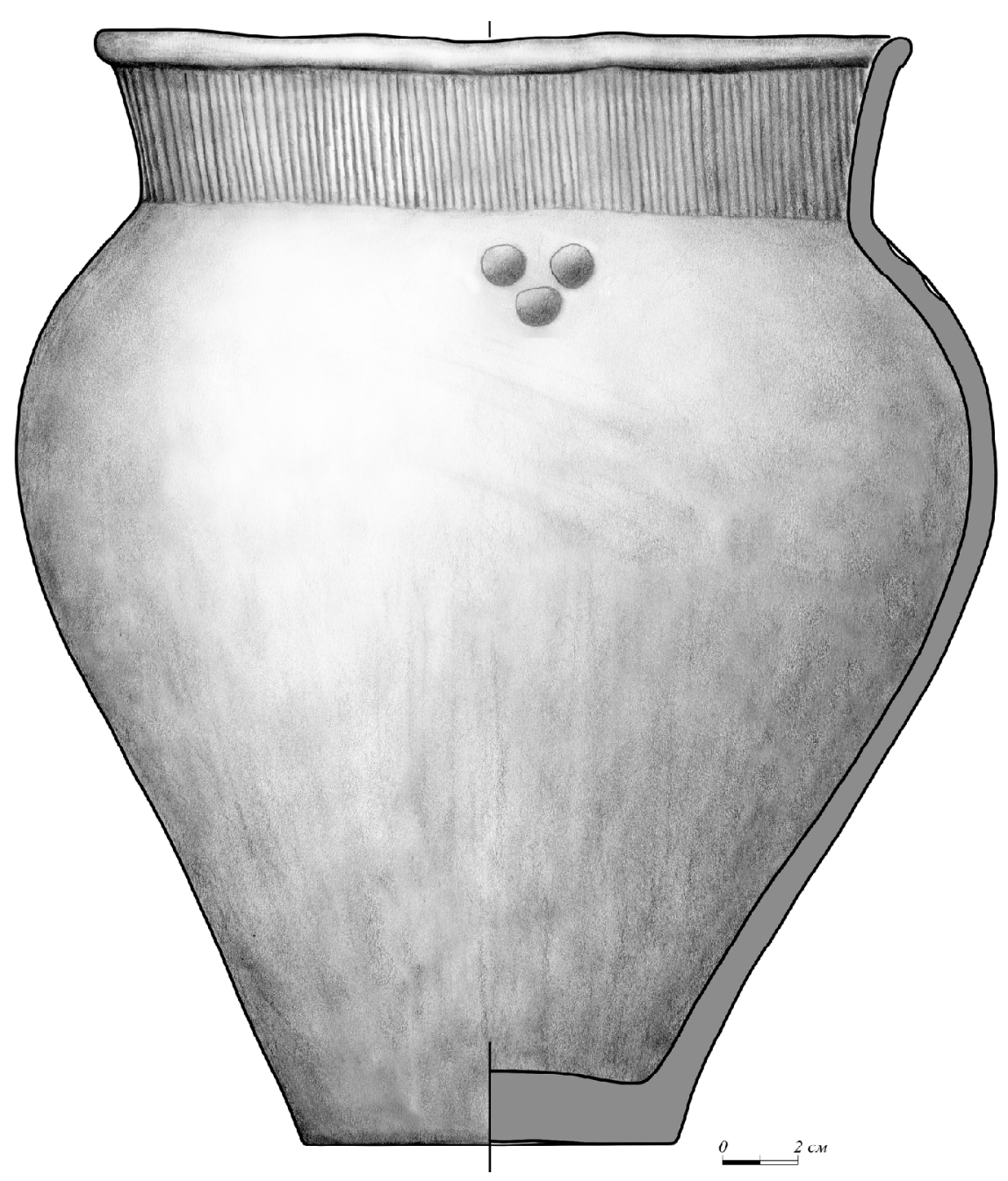

Рис. 3 Лепной горшок из погребения 1/1 могильника Котловина I

Fig. 3. Handmade pot from burial $1 / 1$ of Kotlovina I cemetery 


\section{СПИСОК ЛИТЕРАТУРЫ}

1. Агульников, С. М. Погребально-поминальные комплексы сарматского времени Буджакской степи / С. М. Агульников, С. И. Курчатов // Revista arheologicã. Serie nouã. -2005. - Vol. 1, nr. 2.-C. 285-294.

2. Берестнёв, Р. С. Сарматы в междуречье Хопра и Волги : дис. ... канд. ист. наук / Берестнёв Роман Сергеевич. - Воронеж, 2017. - 323 с.

3. Бруяко, И. В. Никоний римской эпохи / И. В. Бруяко, А. Н. Дзиговский, Н. М. Секерская. - Одесса : СМИЛ, 2008. - 224 с.

4. Бураков, А. В. Козырское городище рубежа первых столетий нашей эры / А. В. Бураков. Киев : Наукова думка, 1976. - 159 с.

5. Гайдукевич, В. Ф. Раскопки Мирмекия в 1935-1938 гг. / В. Ф. Гайдукевич // Материалы и исследования по археологии СССР. - 1952. - № 255. C. $135-223$.

6. Гороховський, Е. Л. Про пізню дату деяких античних городищ Ольвійскоі хори / Е. Л. Гороховський, В. М. Зубар, Н. О. Гаврилюк // Археологія. 1985. - № 49. - С. 25-40.

7. Гросу, В. И. Хронология памятников сарматской культуры Днестровско-Прутского междуречья / В. И. Гросу. - Кишинев : Штиинца, 1990. - 202 с.

8. Гудкова, А. В. Земледельцы и кочевники в низовьях Дуная I-IV вв. н. э. / А. В. Гудкова, М. М. Фокеев. - Киев : Наукова думка, 1984. - 116 с.

9. Гудкова, А. В. Сарматский могильник Градешка в низовьях Дуная / А. В. Гудкова, Е. Ф. Редина // Старожитності Північного Причорномор'я і Криму. - 1999. - Вип. 7. - С. 177-193.

10. Гущина, И. И. Некрополь римского времени Бельбек IV в Юго-Западном Крыму / И. И. Гущина, Д. В. Журавлев. - М. : Ист. музей, 2016. 292 с. - (Труды Государственного исторического музея ; вып. 205).

11. Кастанян, Е. Г. Керамика / Е. Г. Кастанян, Т. М. Арсеньева // Археология СССР. Античные государства Северного Причерноморья. - М. : Наука, 1984. - С. 229-231.

12. Крапивина, В. В. Ольвия. Материальная культура I-IV вв. н. э. / В. В. Крапивина. - Киев : Наукова думка, 1993. - 182 с.

13. Население округи Херсонеса в первой половине I тысячелетия новой эры (по материалам некрополя «Совхоз № 10») / С. Ф. Стржелецкий [и др.] // Stratum plus. - 2003. - № 4. - С. 27-277.

14. Пуздровский, А. Е. Грунтовый склеп 1-2 вв. н. э. с предметами из дерева из Усть-Альминского некрополя / А. Е. Пуздровский, А. Е. Соломоненко // Древняя Таврика. - Симферополь : Универсум, 2007. - С. 207-228.

15. Симоненко, А. В. Сарматы Таврии / А. В. Симоненко. - Киев : Наукова Думка, 1993. - 157 с.
16. Симоненко, А. В. Хронология и периодизация сарматских памятников Северного Причерноморья / А. В. Симоненко // Сарматские культуры Евразии: проблемы региональной хронологии : докл. к 5 Междунар. конф. «Проблемы сарматской археологии и истории». - Краснодар : Кубан. гос. ун-т, 2004. - С. 134-173.

17. Симоненко, А. В. Заметки о погребальном обряде поздних сарматов Северного Причерноморья / А. В. Симоненко // Нижневолжский археологический вестник. - 2011. - № 12. - С. 169-182.

18. Скрипкин, А. С. Нижнее Поволжье в первые века нашей эры / А. С. Скрипкин. - Саратов : Сарат. ун-т, 1984. - 150 с.

19. Субботин, Л. В. Сарматские древности Днестро-Дунайского междуречья. І. Курганные могильники Алкалия и Хаджидер II / Л. В. Субботин, А. Н. Дзиговский. - Киев : Ин-т археологии АН УССР, 1990. - 40 с.

20. Субботин, Л. В. Сарматские древности Днестро-Дунайского междуречья. II. Курганные могильники Дивизийский и Белолесский / Л. В. Субботин, А. Н. Дзиговский. - Киев : Ин-т археологии АН УССР, 1990. $-40 \mathrm{c}$.

21. Субботин, Л. В. Сарматские древности Днестро-Дунайского междуречья. III. Курганные могильники Васильевский и Кубей / Л. В. Субботин, А. Н. Дзиговский. - Киев : Ин-т археологии АНУССР, 1990. $-48 \mathrm{c}$.

22. Фокеев, М. М. Погребальный обряд позднейших сарматских могильников Буджакской степи / М. М. Фокеев // История и археология Нижнего Подунавья. - Рени : Ренийская тип., 1989. C. 86-89.

23. Фокеев, М. М. Сарматский могильник Котловина-I / М. М. Фокеев // Краткие сообщения Одесского археологического общества. - Одесса : Фаворит, 2008. - С. 160-166.

24. Яровой, Е. В. Отчет о полевых исследованиях Прутской новостроечной экспедиции в 1986 г. / Е. В. Яровой // Архив Национального музея истории Молдовы. - № 252.

25. Levițki, O. Necropola tumulară de la Sărăteni / O. Levițki, I. Manzura, T. Demcenko. - Bucureşti : Institul român de Thracologie, 1996. - 156 p.

26. Suceveanu, A. X. La céramique romaine des Ier-IIIer siècles ap. J.-C. / A. X. Suceveanu. - Bucarest : Institut de Mémoire Culturelle, 2000.-191 p. - (Histria. $\mathrm{X}$ : les résultats des fouilles).

\section{REFERENCES}

1. Agulnikov S. M., Kurchatov S. I. Pogrebalnopominalnye kompleksy sarmatskogo vremeni Budzhakskoy stepi [Funeral and Commemorative Complexes of the Sarmatian Time in the Budjak 
Steppe]. Revista arheologicã. Serie nouã, 2005, vol. 1, no. 2, pp. 285-294.

2. Berestnev R.S. Sarmaty v mezhdurechye Khopra i Volgi: dis. ... kand. ist. nauk [Sarmatians in the Interfluve of the Khoper and Volga]. Voronezh, 2017. $323 \mathrm{p}$.

3. Bruyako I.V., Dzigovskiy A.N., Sekerskaya N.M. Nikoniy rimskoy epokhi [Nikonion of the Roman Epoch]. Odessa, SMIL Publ., 2008. 224 p.

4. Burakov A.V. Kozyrskoe gorodishche rubezha pervykh stoletiy nashey ery [Kozyrskoe Fortified Settlement of the Border of First Centuries AD]. Kiev, Naukova Dumka Publ., 1976.159 p.

5. Gaydukevich V.F. Raskopki Mirmekiya v 19351938 gg. [Excavations of the Mirmekion in 1935-1938]. Materialy i issledovaniya po arkheologii SSSR, 1952, no. 255, pp. 135-223.

6. Gorokhovskiy E.L., Zubar V.M., Gavrilyuk N.O. Pro piznyu datu deyakikh antichnikh gorodishch Olviyskoi khori [About the Late Date of Some Antique Fortified Settlements of the Olbian Khora]. Arkheologiya [Archaeology], 1985, no. 49, pp. 25-40.

7. Grosu V.I. Khronologiya pamyatnikov sarmatskoy kultury Dnestrovsko-Prutskogo mezhdurechya [The Chronology of the Sarmatian Culture Sites in the Dniester-Prutus Intefluve]. Kishinev, Shtiintsa Publ., 1990. 202 p.

8. Gudkova A. V., Fokeev M. M. Zemledeltsy $i$ kochevniki v nizovyyakh Dunaya I-IVvv. n. e. [Farmers and Nomads in the Lower Danube Region in the $1^{\text {st }}$ $4^{\text {th }}$ Centuries AD]. Kiev, Naukova Dumka Publ., 1984. $116 \mathrm{p}$.

9. Gudkova A.V., Redina E.F. Sarmatskiy mogilnik Gradeshka v nizovyyakh Dunaya [Sarmatian Cemetery Gradeshka in the Lower Danube Region]. Starozhitnosti Pivnichnogo Prichornomoryya i Krimu [The Antiquities of the North Black Sea Region and Crimea], 1999, iss. 7, pp. 177-193.

10. Gushchina I.I., Zhuravlev D.V. Nekropol rimskogo vremeni Belbek IV v Yugo-Zapadnom Krymu [Necropolis of the Roman Time Belbek IV in the South-East Crimea]. Moscow, Istoricheskiy muzey, 2016. 292 p. (Trudy Gosudarstvennogo istoricheskogo muzeya [Proceedings of the State Historical Museum], iss. 205).

11. Kastanian E.G., Arseneva T.M. Keramika [Ceramics]. Arkheologiya SSSR. Antichnye gosudarstva Severnogo Prichernomoryya [Archaeology of the USSSR. The Antique States of the North Black Sea Region]. Moscow, Nauka Publ., 1984, pp. 229-231.

12. Krapivina V. V. Olviya. Materialnaya kultura $I-I V v v$. n.e. [Olbio. The Material Culture of the $1^{\text {st }}-$ $4^{\text {th }}$ Centuries AD]. Kiev, Naukova Dumka Publ., 1993. $182 \mathrm{p}$.

13. Strzheletskii S. F., Vysotskaia T. N., Ryzhova L.A., Zhestokova G. I. Naselenie okrugi Khersonesa v pervoy polovine I tysyacheletiya novoy ery (po materialam nekropolya «Sovkhoz № 10») [Population of the Chersonese County in the First Half of the $1^{\text {st }}$ millennium AD (On the Materials of the Necropolis "Sovkhoz No. 10")]. Stratum plus, 2003, no. 4, pp. 27-277.

14. Puzdrovskiy A.E., Solomonenko A.E. Gruntovyy sklep 1-2 vv. n. e. s predmetami iz dereva iz Ust-Alminskogo nekropolya [Soil Tomb of the $1^{\text {st }}$ $2^{\text {nd }}$ Centuries AD with Wooden Items from the Ust-Alma Necropolis]. Drevnyaya Tavrika [Ancient Taurica]. Simferopol, Universum Publ., 2007, pp. 207-228.

15. Simonenko A. V. Sarmaty Tavrii [Sarmatians of the Tauria]. Kiev, Naukova Dumka Publ., 1993. 157 p.

16. Simonenko A. V. Khronologiya i periodizatsiya sarmatskikh pamyatnikov Severnogo Prichernomorya [Chronology and Periodization of Sarmatian Sites of the Black Sea Region]. Sarmatskie kultury Evrazii: problemy regionalnoy khronologii: dokl. $k 5$ Mezhdunar. konf. "Problemy sarmatskoy arkheologii i istorii» [Sarmatian Cultures of Eurasia: Problems of the Regional Chronology. Reports of the $5^{\text {th }}$ International Conference "Problems of the Sarmatian Archaeology and History"]. Krasnodar, Kubanskiy gosudarstvennyy universitet, 2004, pp. 134-173.

17. Simonenko A.V. Zametki o pogrebalnom obryade pozdnikh sarmatov Severnogo Prichernomorya [Notes on the Funeral Rite of the Late Sarmatians of the Black Sea Region]. Nizhnevolzhskiy arkheologicheskiy vestnik [The Lower Volga Archaeological Bulletin], 2011, no. 12, pp. 169-182.

18. Skripkin A.S. Nizhnee Povolzhye v pervye veka nashey ery [The Lower Volga Region in the First Centuries AD]. Saratov, Saratovskiy universitet, 1984. $150 \mathrm{p}$.

19. Subbotin L.V., Dzigovskiy A.N. Sarmatskie drevnosti Dnestro-Dunayskogo mezhdurechya. I. Kurgannye mogilniki Alkaliya i Khadzhider II [Sarmatian Antiquities of the Dniester-Danube Interfluve. I. Barrow Cemeteries Alkaliya and Khadzhider II]. Kiev, Institut arkheologii AN USSR, 1990. 40 p.

20. Subbotin L.V., Dzigovskiy A.N. Sarmatskie drevnosti Dnestro-Dunayskogo mezhdurechya. II. Kurgannye mogilniki Diviziiskii i Belolesskii [Sarmatian Antiquities of the Dniester-Danube Interfluve. II. Barrow Cemeteries Diviziyskiy and Belolesskiy]. Kiev, Institut arkheologii AN USSR, 1990. 40 p.

21. Subbotin L.V., Dzigovskiy A.N. Sarmatskie drevnosti Dnestro-Dunayskogo mezhdurechyya. III. Kurgannye mogilniki Vasilevskiy i Kubey [Sarmatian Antiquities of the Dniester-Danube Interfluve. III. Barrow Cemeteries Vasilievka and Kubei]. Kiev, Institut arkheologii AN USSR, 1990. 48 p.

22. Fokeev M.M. Pogrebalnyy obryad pozdneyshikh sarmatskikh mogilnikov Budzhakskoy 
stepi [Funeral Rite of the Latest Sarmatian Cemeteries in the Budjak Steppe]. Istoriya i arkheologiya Nizhnego Podunavya [History and Archaeology of the Lower Danube Region]. Reni, Reniyskaya tipografiya, 1989, pp. 86-89.

23. Fokeev M.M. Sarmatskiy mogilnik Kotlovina-I [Sarmatian Cemetery Kotlovina-I]. Kratkie soobshcheniya Odesskogo arkheologicheskogo obshchestva [Short Communications of the Odessa Archaeological Society]. Odessa, Favorit Publ., 2008, pp. 160-166.
24. YarovoyE.V. Otchet o polevykh issledovaniiakh Prutskoi novostroechnoi ekspeditsii v 1986 g. [Field Report on the Study of the Prutus Rescue Expedition on 1986]. Arkhiv Natsionalnogo muzeya istorii Moldovy [Archive of the National Museum of History of Moldova], no. 252.

25. Levițki O., Manzura I., Demcenko T. Necropola tumulară de la Sărăteni. Bucureşti, Institul român de Thracologie, 1996. 156 p.

26. Suceveanu A.X. La céramique romaine des Ier-IIIer siècles ap. J.-C. Bucarest, Institut de Mémoire Culturelle, 2000. 191 p. (Histria. X: les résultats des fouilles).

\section{Information About the Authors}

Sergey O. Simonenko, Researcher, Scientific Laboratory "Archaeology", Pridnestrovian State University named after T.G. Shevchenko, 25 Oktyabrya St, 128, 3300 Tiraspol, Pridnestrovian Moldavian Republic, simon_mid@mail.ru. https://orcid.org/0000-0001-6760-2565

Sergey D. Lysenko, Candidate of Sciences (History), Senior Researcher, Department of Archaeology of the Eneolithic and Bronze Age, Institute of Archaeology of the National Academy of Sciences of Ukraine, Prosp. Geroev Stalingrada, 12, 04210 Kiev, Ukraine, suraganga@yandex.ru, https://orcid.org/0000-0001-9624-0364

Sergey N. Razumov, Candidate of Sciences (History), Senior Researcher, Scientific Laboratory “Archaeology", Pridnestrovian State University named after T.G. Shevchenko, 25 Oktyabrya St, 107, 3300 Tiraspol, Pridnestrovian Moldavian Republic, razum_22@rambler.ru, https://orcid.org/0000-0001-6030-9390

Vitalij S. Sinika, Candidate of Sciences (History), Associate Professor, Head of Scientific Laboratory “Archaeology", Pridnestrovian State University named after T.G. Shevchenko, 25 Oktyabrya St, 107, 3300 Tiraspol, Pridnestrovian Moldavian Republic, sinica80@mail.ru, https://orcid.org/0000-0002-1621-9205

\section{Информация об авторах}

Сергей Олегович Симоненко, научный сотрудник НИЛ «Археология», Приднестровский государственный университет им. Т.Г. Шевченко, ул. 25 Октября, 128, 3300 г. Тирасполь, Приднестровская Молдавская Республика, simon_mid@mail.ru, https://orcid.org/0000-0001-6760-2565

Сергей Дмитриевич Лысенко, кандидат исторических наук, старший научный сотрудник отдела археологии энеолита - бронзового века, Институт археологии Национальной академии наук Украины, просп. Героев Сталинграда, 12, 04210 г. Киев, Украина, suraganga@yandex.ru, https://orcid.org/0000-0001-9624-0364

Сергей Николаевич Разумов, кандидат исторических наук, старший научный сотрудник НИЛ «Археология», Приднестровский государственный университет им. Т.Г. Шевченко, ул. 25 Октября, 107, 3300 г. Тирасполь, Приднестровская Молдавская Республика, razum_22@rambler.ru, https://orcid.org/0000-0001-6030-9390

Виталий Степанович Синика, кандидат исторических наук, доцент, заведующий НИЛ «Археология», Приднестровский государственный университет им. Т.Г. Шевченко, ул. 25 Октября, 107, 3300 г. Тирасполь, Приднестровская Молдавская Республика, sinica80@mail.ru, https://orcid.org/0000-0002-1621-9205 